\title{
Comparison of the Biochemical Activities of Commercial Yogurts and Lactobacillus acidophilus-containing Yogurt
}

\author{
Jae-Ki Ryu ${ }^{1}$, Hyeong-Seon Lee ${ }^{2}$, Bon-Kyung Koo ${ }^{3}$, and Hyun-Kyung Kim ${ }^{1}$ \\ ${ }^{1}$ Department of Biomedical Laboratory Science, Gimcheon University, Gimcheon 740-704, Korea \\ ${ }^{2}$ Department of Biomedical Laboratory Science, Jungwon University, Chungbuk 367-700, Korea \\ ${ }^{3}$ Department of Laboratory Medicine, Samsung Medical Center, Seoul 135-710, Korea
}

\section{시판용 요구르트와 Lactobacillus acidophilus 요구르트의 생화학적 활성의 비교}

\author{
류재기 ${ }^{1}$, 이형선 ${ }^{2}$, 구본경 $^{3}$, 김현경 $^{1}$ \\ ${ }^{1}$ 김천대학교 임상병리학과, ${ }^{2}$ 중원대학교 임상병리학과, ${ }^{3}$ 삼성서울병원 진단검사의학과
}

\begin{abstract}
Lactic acid-producing bacteria such as Lactobacillus spp. function to ferment carbohydrates and produce ATP. Such Lactobacillus spp. are used for the production of commercial yogurts. Lactobacillus spp. are beneficial to the intestinal tract, and Lactobacillus acidophilus-containing yogurts have received considerable attention because of their preventive effects against early-stage cancer of the large intestine. In this study, lactic acid-producing bacteria were cultured from three different groups: commercial solid yogurt (for eating), commercial liquid yogurt (for drinking), and Lactobacillus acidophilus-containing yogurt. We first determined the optimum culture conditions for Lactobacillus spp. and then analyzed turbidity and $\mathrm{pH}$ in order to compare the growth abilities and lactic acid-production capacities among the groups. Finally, high-performance liquid chromatography was used to measure the lactic acid content in the culture supernatants, and the antibacterial activities against Staphylococcus aureus and Escherichia coli were compared among the three groups. The optimum culture conditions for Lactobacillus spp. were MRS medium at $25^{\circ} \mathrm{C}$, for $24 \mathrm{~h}$. The highest turbidity was found in L. acidophilus-containing yogurt, followed by liquid yogurt and solid yogurt. Similarly, the highest lactic acid production ability was found in $L$. acidophilus-containing yogurt, followed by liquid yogurt and solid yogurt. Culture supernatants from the three groups did not show any antibacterial activity towards $S$. aureus; however, supernatants derived from L. acidophilus-containing yogurt resulted in a $1.8 \mathrm{~mm}$ inhibitory zone against $E$. coli in a paper disk diffusion test. These results revealed the high level of lactic acid-production capacity and antibacterial activity in L. acidophilus-containing yogurt.
\end{abstract}

Keywords: Lactobacillus acidophilus, Yogurt, Lactic acid, Antibacterial activity

This is an Open Access article distributed under the terms of the Creative Commons Attribution Non-Commercial License (http://creativecommons.org/licenses/by-nc/4.0) which permits unrestricted non-commercial use, distribution, and reproduction in any medium, provided the original work is properly cited

Copyright @ 2015 The Korean Society for Clinical Laboratory Science. All rights reserved.
Corresponding author: Hyun-Kyung Kim Department of Biomedical Laboratory Science, Gimcheon University, Gimcheon 740-704, Korea

Tel: 82-54-420-4041

E-mail:khj9626@naver.com

Received: April 21, 2015

Revised: June 4, 2015

Accepted: June 4, 2015

\section{Introduction}

Lactic acid-producing bacteria such as Lactobacillus spp., which ferment carbohydrates and produce ATP (Kandler,
1983) are known for their considerable benefits to the health of the human intestine. Indeed, probiotic substances produced by Lactobacillus spp. are used in the food and pharmaceutical industries for manufacturing products that maintain 
the stability of the normal intestinal flora. These probiotic substances have various effects on the physiology and health of individuals. For example, these probiotics have been shown to protect against cancer, decrease cholesterol levels in the blood, promote the growth of beneficial bacteria, and improve the absorption of lactose (Robinson et al., 1984; Kim et al., 1993; Andersson et al., 2001; Ranadhheera et al., 2010; Ooi and Liong, 2010). Additionally, Lactobacillus acidophilus has been shown to prevent the development of cancer of the large intestine (Wollowski et al., 2001). Thus, Lactobacillus spp. have a range of biological effects that are beneficial to health.

In the food industry, Lactobacillus spp. are used extensively for producing cheese, bean paste, fermented milk, kimchi, soy sauce, yogurt, and yogurt-based products (Sugiyama, 1984; Lücke, 1996; Leory and Vuyst, 2004; Lee et al., 2011). Yogurt is classified into solid and liquid types. Solid-type yogurt was first introduced in Korea in 1981. Since the early 1970s, after the sale of liquid-type yogurt containing $3 \%$ milk solids produced by Japan, the consumption of yogurt has increased dramatically every year. Moreover, consumption of solid yogurt is gradually increasing in consumers with a high standard of living.

Staphylococcus aureus is a gram-positive bacterium isolated from the nasal cavities of healthy adult and from sites of infection; this bacterium is association with hospital and community-acquired infections (Kim, 2012; Han and Kim, 2014). Some strains of $S$. aureus are resistant to antimicrobial agents (Kim, 2012; Han and Kim, 2014). Escherichia coli is a part of the normal flora of the human intestine; however, this bacterium can occasionally cause opportunistic infection and exhibit antimicrobial resistance (Lee and Choi, 2007; Kim et al., 2012; Sung et al., 2013).

Although many commercial yogurts have been used to promote health, the content and activities of lactic acid bacteria in solid and liquid yogurts have not been fully elucidated. Therefore, in this study, we aimed to compare the lactic acid-producing capacities and antibacterial activities of commercial solid and liquid yogurts and a homemade yogurt containing L. acidophilus. We expect that our results will provide important insights into the production of more effective probiotic yogurts.

\section{Materials and Methods}

\section{Materials}

Solid and liquid-type yogurts from three different companies purchased from local supermarkets and a single strain of L. acidophilus were included in this study. All materials were analyzed within $24 \mathrm{~h}$ after storage at $10^{\circ} \mathrm{C}$ in a refrigerator.

\section{Culture and preprocessing}

One milliliter of each sample type (solid yogurt, liquid yogurt and L. acidophilus-containing yogurt) was cultured in 200 mL MRS broth with Tween 80 (MB Cell, Los Angeles, CA, USA) for $24 \mathrm{~h}$ in an incubator (J-2000, JISICO, Seoul, Korea) at $25^{\circ} \mathrm{C}$ and centrifuged three times at $3000 \mathrm{rpm}$ for $1 \mathrm{~min}$. The turbidity of each sample was adjusted to 0.5 McFarland units by spectrophotometry (MAP LAB PLUS, BSI, Arezzo, Italy) at $630 \mathrm{~nm}$. The cultures for the three groups were maintained in incubators at $37^{\circ} \mathrm{C}$ or $25^{\circ} \mathrm{C}$ and divided into subgroups on the basis of incubation time $(24,48$, or $72 \mathrm{~h}$ ) in MRS broth with Tween 80 .

\section{3. $\mathrm{pH}$ analysis}

$\mathrm{pH}$ was determined for each sample more than three times with a pH meter (HM-25R, Analyticon, Springfield, NJ, USA) at $25^{\circ} \mathrm{C}$. Buffers at $\mathrm{pH} 4.01$ and $\mathrm{pH} 6.86$ were used for calibration.

\section{Turbidity test}

Commercial yogurts from three different companies (a, b, and c; $100 \mathrm{~mL}$ each) and a strain of L. acidophilus were cultured in MRS broth with Tween 80 for $24 \mathrm{~h}$ at $25^{\circ} \mathrm{C}$. The absorbance was then measured at $630 \mathrm{~nm}$ by spectrophotometry. Sterile MRS broth with Tween 80 was used for blank samples.

\section{High-performance liquid chromatography (HPLC) analysis}

Lactic acid was used as the index component. Culture supernatants were obtained from $24 \mathrm{~h}$ cultures in MRS broth 
with Tween 80 by centrifugation at $3000 \mathrm{rpm}$ for $10 \mathrm{~min}$.

The HPLC system (LC-20AD, Shimadzu, Nakagyo, Kyoto, Japan) comprised a pump, auto sampler, RS column compartment, UV-VIS detector, photo-diode array detector, high-pressure switching valve, and column (Shiseido, Minato-ku, Tokyo, Japan) maintained at $30^{\circ} \mathrm{C}$. The mobile phase was $0.1 \%$ phosphoric acid: acetonitrile (9:1). The wavelength was measured at $254 \mathrm{~nm}$ at a flow rate of 1.0 $\mathrm{mL} / \mathrm{min}$. The injection volume was $10 \mu \mathrm{L}$.

\section{Antibacterial activity}

Sensitivity tests were conducted to investigate the antibacterial effects of the solid-type, liquid-type, and $L$. acidophilus-containing yogurts against two strains of bacteria commonly associated with food poisoning, namely $S$. aureus (ATCC 25923), and E. coli (ATCC 25922). Nutrient broth (BD, Franklin Lakes, NJ, USA) was used for culturing both $S$. aureus and E. coli. Mueller-Hinton agar (BD) was used for the sensitivity tests. Frozen samples of $S$. aureus and $E$. coli were cultured for $24 \mathrm{~h}$ in TSB (BD). Next, each strain was mixed in $0.85 \%$ saline and the mixture was adjusted to a turbidity of 0.5 McFarland units (spectrophotometer, 630 $\mathrm{nm})$. Twenty microliters of each yogurt culture supernatant obtained from $24 \mathrm{~h}$ cultures in MRS broth with Tween 80 was dispensed onto paper disks for the disk diffusion assay.

\section{Statistical analysis}

All experiments were repeated at least three times. The results are presented as the mean \pm standard deviation (SD). All experimental data were analyzed using the SPSS program (SPSS 18.0, SPSS Institute, Chicago, IL, USA). One-way analysis of variance (ANOVA) with Duncan's multiple range tests was used to examine the differences between groups. Differences with $p$ values of less than $<0.05$ were considered statistically significant.

\section{Results}

\section{Turbidity test}

Increased turbidity suggests the growth of bacteria. Liquid yogurt was found to have a significantly higher absorbance than solid yogurt, while L. acidophilus-containing yogurt had a significantly higher absorbance than liquid yogurt (Fig. 1). These data implied that L. acidophilus-containing yogurt had the highest growth ability among the three groups.

\section{2. $\mathrm{pH}$ meter analysis}

$\mathrm{pH}$ is indicative of acid-producing activity. The lowest $\mathrm{pH}$ was in the L. acidophilus-containing yogurt followed by liquid yogurt and solid yogurt (Fig. 2). Thus, the L. acidophilus-containing yogurt had the highest lactic acid production, while solid yogurt had the lowest. However, the $\mathrm{pH}$ values of the liquid yogurt and L. acidophilus-containing yogurt were not significantly different.

\section{HPLC analysis}

HPLC analysis revealed that lactic acid production was in the order of L. acidophilus-containing yogurt > liquid yogurt

(A)

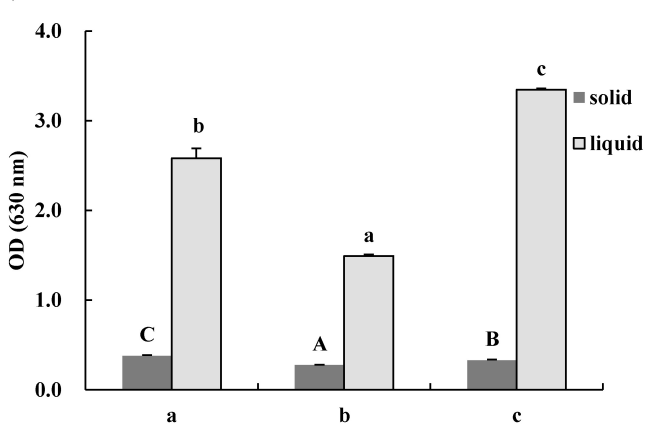

(B)

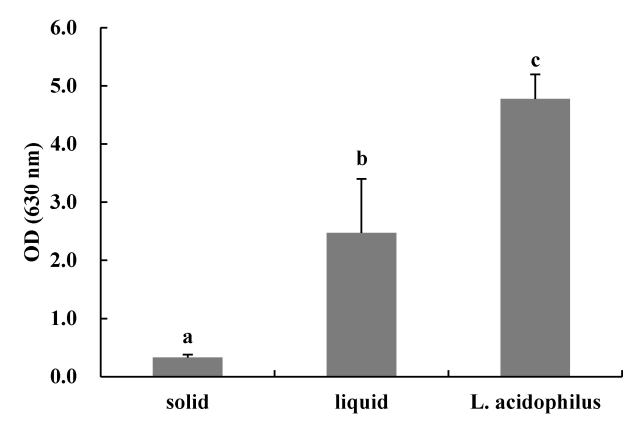

Fig. 1. Comparison of absorbances in commercial solid and liquid yogurts and L. acidophilus-containing yogurt. (A) Comparison of the absorbances of commercial yogurts ( $a, b$, and $\mathrm{c}$ indicate commercial yogurts from three different companies). (B) Comparison of the mean absorbances of solid and liquid yogurts in $(A)$ and L. acidophilus-containing yogurt. Values with different superscripts were significantly different at $p<0.05$. 
$>$ solid yogurt (Fig. 3).

\section{Antibacterial activity}

Culture supernatants from the commercial yogurts and $L$. acidophilus-containing yogurt did not show any antibacterial

(A)

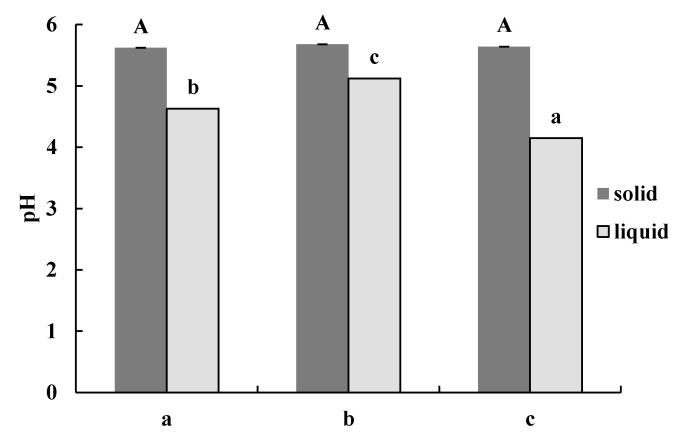

(B)

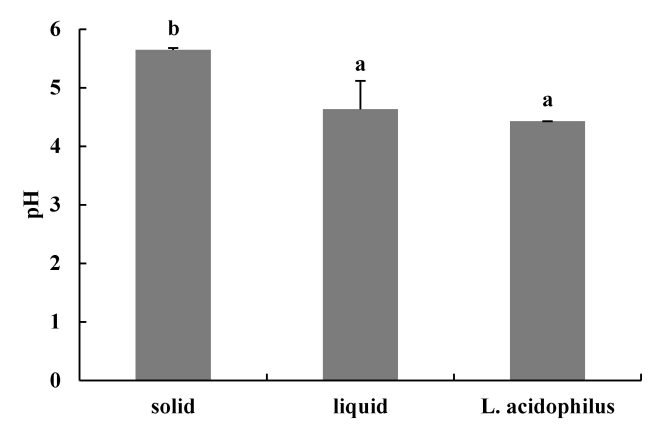

Fig. 2. Comparison of the $\mathrm{pH}$ of commercial solid and liquid yogurts and $L$. acidophilus-containing yogurt. (A) Comparison of $\mathrm{pH}$ values of commercial yogurts ( $a, b$, and $c$ indicate commercial yogurts from three different companies). (B) Comparison of mean $\mathrm{pH}$ values of solid and liquid yogurts in (A) and L. acidophilus-containing yogurt. Values with different superscripts were significantly different at $p<0.05$. activity against $S$. aureus (data not shown). However, $L$. acidophilus-derived supernatants showed an inhibitory zone of $1.8 \mathrm{~mm}$ in response to $E$. coli in a paper disk diffusion test (Fig. 4).

\section{Discussion}

In this study, culture turbidity and $\mathrm{pH}$ were measured to compare the growth ability and lactic acid production among solid-type, liquid-type, and L. acidophilus-containing yogurt. L. acidophilus-containing yogurt had the highest turbidity and lowest $\mathrm{pH}$. Additionally, L. acidophilus-containing yogurt exhibited the highest lactic acid production, followed by

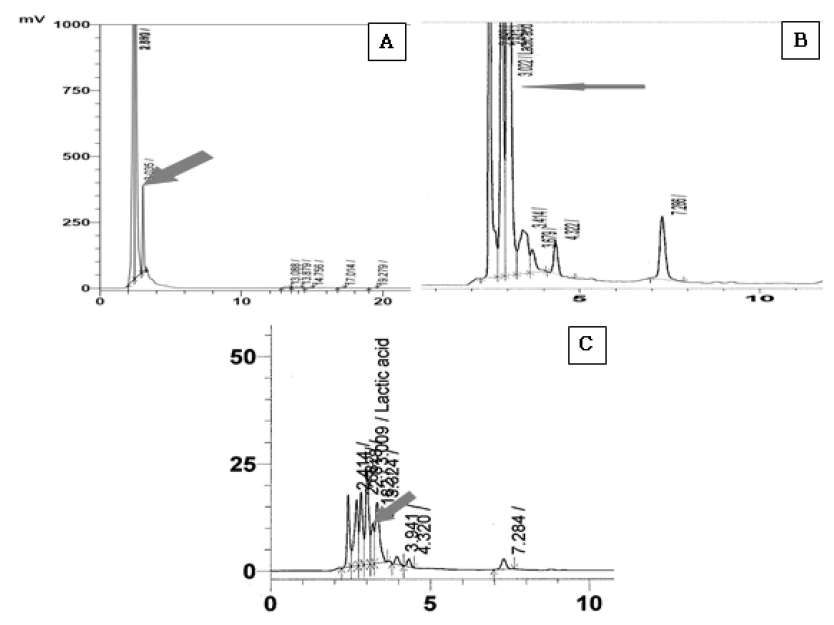

Fig. 3. HPLC chromatograms of commercial yogurts and L. acidophilus-containing yogurt. (A) Liquid yogurt (area: 1887126), (B) L. acidophilus-containing yogurt at $25^{\circ} \mathrm{C}$ (area: 3455638), (C) Solid yogurt at $25^{\circ} \mathrm{C}$ (area: 161772).
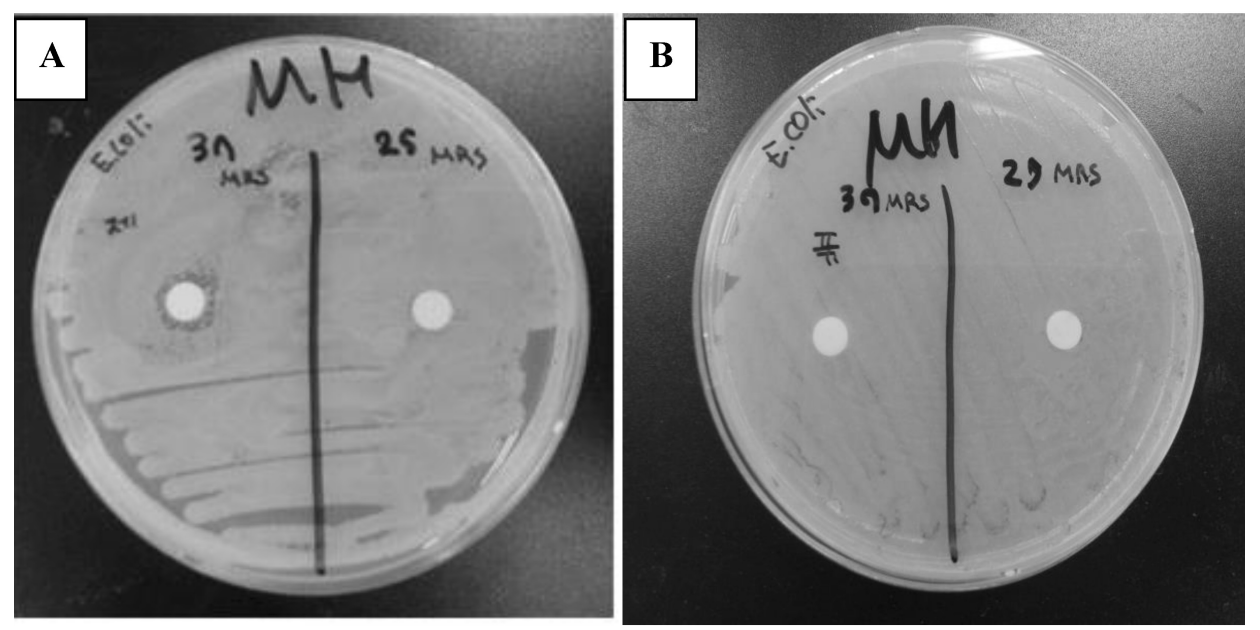

Fig. 4. E. coli inhibition zones induced by $L$. acidophilus-containing yogurt and commercial yogurt. (A) E. coli inhibition by L. acidophilus-containing yogurt $(1.8 \mathrm{~mm})$, (B) E. coli inhibition by commercial yogurt. 
liquid yogurt and solid yogurt. L. acidophilus-containing yogurt also showed the highest antibacterial activity. Thus, our data provide important insights into the production of more effective probiotic yogurts.

Lactic acid is a weak-organic acid and plays a role in diverse biochemical processes (Ibrahim et al., 2008). Ibrahim et al. (2008) reported that lactic acid inhibits the growth of pathogens such as Salmonella and E. coli and Alakomi et al. (2000) showed that lactic acid exerts antimicrobial activity through inducing the permeabilization of gram-negative bacteria and lowering of the $\mathrm{pH}$.

$S$. aureus and E. coli can cause hospital and communityacquired infections or opportunistic infection. Moreover, some strains show resistance to antimicrobial agents (Lee and Choi, 2007; Kim, 2012; Kim et al., 2012; Sung et al., 2013; Han and Kim, 2014). In our study, L. acidophilus-containing yogurt showed antibacterial ability against $E$. coli but, not against $S$. aureus. High lactic acid production was also observed for this sample. These data indicated that L. acidophilus may be a source of antibacterial substances.

In summary, L. acidophilus-containing yogurt had high lactic acid production and antimicrobial activity. Thus, further studies are warranted to ascertain whether commercial food products produced using L. acidophilus may also affect other substances within the human gastrointestinal tract, including gastric acids, bile salts, or various enzymes.

\section{요 약}

Lactobacillus spp.같은 유산균은 탄수화물을 발효하여 ATP를 생성하며, 시판되는 요구르트 생산에 이용되고 있다. Lactobacillus spp.는 장관계 건강에 유익한 균으로, 특히 Lactobacillus acidophilus를 함유하는 요구르트는 대장암 초기단계를 예방하는 효과가 있는 것으로 나타나 관심이 모아지고 있다. 본 연구에서는 고형 요구르트와 액상 요구르트, 그리고 Lactobacillus acidophilus 세 그룹의 유산균을 배양하였다. 먼저 Lactobacillus spp. 의 최적의 배양조건을 조사하였고 세 그룹의 생장능과 젖산생성을 비교하기 위해 혼탁도와 $\mathrm{pH}$ 를 측정하였다. 배양 상층액의 젖산을 비교하기 위해 HPLC를 시행하였으며 Staphylococcus aureus와 Escherichia coli에 대한 항균력을 측정하였다. Lactobacillus $\mathrm{spp}$.의 최적의 배양조건은 $25^{\circ} \mathrm{C}$ 의 온도로 MRS배지에서 24 시간 배양이었다. 혼탁도와 젖산 생성은 L. acidophilus가 가장 높았고
액상 요구르트, 고형 요구르트 순으로 나타났다. Paper disk법을 이용한 항균력 시험에서는 S. aureus에 대해서는 세 그룹 모두 항균 력이 없었으며 E. coli에 대해서는 L. acidophilus에서 $1.8 \mathrm{~mm}$ 의 억제대를 보였다. 이 연구결과로 L. acidophilus는 높은 젖산 생성 능력과 항균력을 가지고 있음을 확인하였다.

Acknowledgements: This study was financially supported by Gimcheon University.

Funding: None

Conflict of interest: None

\section{References}

1. Alakomi HL, Skytta E, Saarela M, Mattila-Sandholm T, LatvaKala K, Helander IM. Lactic acid permeabilizes gram-negative bacteria by disrupting the outer membrane. Applied and Environmental Microbiology. 2000,66:2001-2005.

2. Andersson H, Asp NG, Bruce A, Roos S, Wadstrom T, Wold AE. Health effects of probiotics and prebiotics A literature review on human studies. Scand J Nutr. 2001,45: 58-75.

3. Han DH, Kim HC. Rapid detection of methicillin resistant Staphylococcus aureus based on surface enhanced raman scattering. Korean J Clin Lab Sci. 2014,46:136-139.

4. Ibrahim SA, Yang H, Seo CW. Antimicrobial activity of lactic acid and copper on growth of Salmonella and Escherichia coli 0157:H7 in laboratory medium and carrot juice. Food Chemistry. 2008,109:137-143.

5. Kandler O. Carbohydrate metabolism in lactic acid bacteria. Antonie van Leeuwenhoek. 1983,49:209-224.

6. Kim BY, Thyiam G, Kang JE, Lee SH, Park SH, Kim JS, et al. Development of an Escherichia colibiofilm model on transwell. Korean J Clin Lab Sci. 2012,44:112-117.

7. Kim CH, Lee JY, Kim MK, Kim SH, Park GY, Bae SY, et al. Isolation rate of methicillin-resistant Staphylococcus aureus (MRSA) from nasal cavity inferior regions and cellular phones. Korean J Clin Lab Sci. 2012,44:118-123.

8. Kim MS, Ahn ES, Shin DH. Physico-chemical properties of commercial yoghurt in Korea. Korean J Food Sci Technol. 1993, 25:340-344.

9. Lee HJ, Yoon HS, Ji YS, Kim HN, Park HJ, Lee JE, et al. Functional properties of Lactobacillus strains isolated from kimchi. International Journal of Food Microbiology. 2011,145: 155-161.

10. Lee MH, Choi CS. Antimicrobial resistance profiles of eae positive Escherichia coli. J Fd Hyg Safety. 2007,22:116-119.

11. Leroy F, Vuyst LD. Lactic acid bacteria as functional starter cultures for the food fermentation industry. Trends in Food Science \& Technology. 2004,15:67-78.

12. Lücke FK. Lactic acid bacteria involved in food fermentations and their present and future uses in food industry. Lactic Acid Bacteria NATO ASI Series. 1996,98:81-99.

13. Ooi LG, Liong MT. Cholesterol-lowering effects of probiotics and prebiotics: A review of in vivo and in vitro fndings. Int J Mol 
64 Jae-Ki Ryu, et al. Comparison between Commercial Yogurts and L. acidophilus

Sci. 2010,11:2499-2522.

14. Ranadheera RDCS, Baines SK, Adams MC. Importance of food in probiotic efficacy. Food Research International. 2010,43: $1-7$.

15. Robinson IM, Whipp SC, Bucklin JA, Allison MJ. Characterization of predominant bacteria from the colons of normal and dysenteric pigs. Applied and Environmental Microbiology. 1984,33:79-85.

16. Sugiyama SI. Selection of micro-organisms for use in the fer- mentation of soy sauce. Food Microbiology. 1984,1:339-347.

17. Sung JY, Oh JE, Kim ES, Son JM, Kim HY, Lim DY. Spread of CTX-M extended-spectrum $\beta$-lactamase producing Escherichia coli in the community in Chungcheong area, Korea. Korean J Clin Lab Sci. 2013,45:43-47.

18. Wollowski I, Rechkemmer G, Pool-Zobel BL. Protective role of probiotics and prebiotics in colon cancer. Am J Clin Nutr. 2001,73:451S-455S. 